\title{
Action research workshop for transdisciplinary sustainability science
}

\author{
G. Tejedor, J. Segalas \\ Research Institute for Sustainability Science and Technology , Universitat Politècnica de \\ Catalunya - Barcelona Tech, Spain. \\ jordi.segalas@upc.edu
}

\begin{abstract}
The Research Institute for Sustainability Science and Technology under the Master degree in Sustainability Science and Technology organises the course Action Research Workshop on Science and Technology for Sustainability (5 ECTS). The authors have been coordinating the course during the academic years 13/14, 14/15 and 15/16. The purpose of the workshop is to put together civil society organisations, local administrations, students and educators to collaboratively undertake responsible research, performing transdisciplinary learning environments and using actionresearch framework, to answer questions such as: Who are we researching for? Who profits from our research? What are the impacts of our research? Which methodologies and tools should be used? While dealing with sociotechnical sustainability challenges.

Students work on real projects, related to local sustainability problems, represented by a community entity (Service learning and Campus Lab). Action research methodology is used with a two-cycle approach. In each real-life project, students, faculty and stakeholders are asked to follow the actionreflexion process of action research projects: Action 1- Jointly defining: Project purpose; Customer and interest; Involved actors; Reflexion 1- Students define: research question, initial situation, needed additional information, action Strategy, Tasks planning and distribution: Action 2 - Items returning and discussing with stakeholders, Reflexion 2 - revising and reformulating.

After three editions, we can conclude that: First, students realized the significance of framing an investigation under a research methodological framework that allows bringing research to the community, enhancing transdisciplinarity in any initiative or action in sustainability science. They set out the importance of some topics and the difficulty to hold them. Second, the formulation of the problem became one of the most arduous task in the process; difficulties were mainly related to the perception of the problem from distinct community group motivations. Third, interaction and communication with stakeholders and the recognition of their role was problematic as usually engineering students are not train to work in wicked problems and accompanying stakeholders during the whole process. Finally, it is relevant to highlight that during the process students faced conflict and frustrating situations, within their team and with stakeholders. To face that, an Emotional Intelligence module was introduced in the workshop and helped students to solve some paralyzing situations, which could have stopped the progress of the project. We suggest that engineering students need specific training in transdisciplinary research and in conflict resolution, otherwise they could collapse in frustration when dealing with real transdisciplinary sustainability transitions.
\end{abstract}




\section{Introduction}

Sustainability issues are widely recognized as wicked problems (Yearworth, 2016), which should not be considered as problems to be solved, but as conditions to be governed (Seager et al., 2011). There is a general agreement on the need to reform scientific expertise, as it is required to deal with sustainability challenges, by developing new ways of knowledge production and decision-making. In that sense, Stephen Sterling (2005) maintains that the nature of sustainability requires a fundamental change of epistemology, and therefore, of education. In relation to technological education, the Barcelona Declaration (2004) approved during the Engineering Education in Sustainable Development (EESD) conference in 2004 declares that today's engineers must be able to:

- Understand how their work interacts with society and the environment, locally and globally, in order to identify potential challenges, risks and impacts.

- Understand the contribution of their work in different cultural, social and political contexts and take those differences into account.

- Work in multidisciplinary teams, in order to adapt current technology to the demands imposed by sustainable lifestyles, resource efficiency, pollution prevention and waste management.

- Apply a holistic and systemic approach to solving problems, and have the ability to move beyond the tradition of breaking reality down into disconnected parts.

- Participate actively in the discussion and definition of economic, social and technological policies, to help redirect society towards more sustainable development.

- Apply professional knowledge according to deontological principles and universal values and ethics.

- Listen closely to the demands of citizens and other stakeholders and let them have a say in the development of new technologies and infrastructures.

The Universitat Politècnica de Catalunya (UPC Barcelona Tech), aware of the new competences that engineers should have, offers a master degree in Sustainability Science and Technology. The aim of the master's degree is to provide advanced training in sustainable human development that enables students to understand the complex interaction between society, technology, the economy and the environment, so that they can tackle the social and environmental challenges inherent to sustainability: climate change, the depletion of natural resources, North-South imbalances, environmental justice, etc. This master degree trains students to become entrepreneurial professionals and agents of change for sustainability who will, depending on their specialization, design and assess global, sustainable solutions for the uncertain, complex scenario in which we live. They take a transdisciplinary approach and ensure scientific and technical rigor in the diverse cultural and professional contexts in which they work.

Within the Master, there is the course Action Research Workshop on Sustainability Science and Technologies. Next sections explain the learning environment and the challenges and lessons learnt when organizing such a course, as well as the learning results obtained by students.

\section{Action Research Workshop on Sustainability Science and Technologies Course}

The Action Research Workshop on Sustainability Science and Technologies (ARW) is a course within the Master of Sustainability Science and Technology offered by Barcelona Tech University. It is a 5 ECTS (European Credit transfer System) course, which uses constructive and community oriented learning which has shown to be the most efficient way to train students in sustainability science competences (Segalas, 2006; Segalas et al., 2010). 


\subsection{Goals and learning outcomes}

The purpose of the workshop is to put together civil society organisations, local administrations, students and educators to collaboratively undertake responsible research, using transdisciplinary Action-Research methodologies, to answer questions such as: Who are we researching for? Who profits from our research? What are the impacts of our research? Which methodologies and tools should be used? While dealing with sociotechnical sustainability challenges.

When finishing the course students will have been trained in the next competences.

- To know and understand the research paradigms (positivist, interpretive, critical theory and pragmatism) on which the research theories, methodology, and methods are based.

- To be able to choose the most suitable research paradigm to tackle a real sustainability challenge.

- To be able to work in transdisciplinary research settings.

- To know, understand and be able to apply the action research methodology and research tools (quantitative and qualitative) in real-life contexts.

- Understand how their work interacts with society and the environment, locally and globally, in order to identify potential challenges, risks and impacts

- To reflect in the results of the research process and the research process itself in order to understand the social dynamics that appear when applying transdisciplinary approach in real sustainability challenges

\subsection{Course organization}

Research paradigms and Action Research methodology

The course is organized around five areas (Fig. 1): Research paradigms, Action research methodologies, Dimensions of Action Research, Research tools and Reals projects.

Figure 1: Workshop in Action Research scheme

First students are faced with different research paradigms (Table 1) and its features in order to facilitate their reflection on the research that they have/are/will apply in their work as researchers. This is necessary because most of the students come from technological education holding a bachelor or master degree in engineering or architecture, and they usually only have been working with the positivist research paradigm which when working with sustainability challenges with embedded social issues is not usually the most appropriated (Martens, 2006).

Next, students are trained in Action Research methodologies. Starting with definitions (Wallace, 1987, Edwards \& Talbot, 2014; Carr and Kemmis, 2009) and its main features (Whitehead \& McNiff, 2002; Noffke, 2009) which can be sum up as:

- all the participants have something to contribute and to learn

- participants as co-researchers and co-learners, including the researcher

- knowledge and theory are inseparable from practice

- the main purpose is the improvement of a real situation or problem

- reflection and action are two core elements

- the whole learning-by-doing process is what counts 
Once students are familiar with the main characteristics of action research, they learn about the main types of action research: i) Participatory action research (Baum et al., 2006); ii) Action learning (Revans, 2011; Kember, 2000); iii) Critical action research (Tripp, 1990) and iv) Collaborative inquiry (Coughlan and Coghlan, 2011). Students study their main features, pros and cons, methodological approaches and examples.

Table 1: Four scientific paradigms. (Sobh and Perry, 2005)

\begin{tabular}{|c|c|c|c|c|}
\hline \multirow[b]{2}{*}{ Element } & \multicolumn{4}{|c|}{ Paradigm } \\
\hline & Positivism & Constructivism & Critical theory & Realism \\
\hline Ontology & $\begin{array}{l}\text { Reality is real and } \\
\text { apprehensible }\end{array}$ & $\begin{array}{l}\text { Multiple local and } \\
\text { specific } \\
\text { "constructed" } \\
\text { realities }\end{array}$ & $\begin{array}{l}\text { "Virtual” reality } \\
\text { shaped by social, } \\
\text { economic, ethnic, } \\
\text { political, cultural, } \\
\text { and gender values, } \\
\text { crystallised over time }\end{array}$ & $\begin{array}{l}\text { Reality is "real” but } \\
\text { only imperfectly and } \\
\text { probabilistically } \\
\text { apprehensible and so } \\
\text { triangulation from } \\
\text { many sources is } \\
\text { required to try to } \\
\text { know it }\end{array}$ \\
\hline Epistemology & $\begin{array}{l}\text { Findings true - } \\
\text { researcher is } \\
\text { objective by viewing } \\
\text { reality through a } \\
\text { "one-way mirror" }\end{array}$ & $\begin{array}{l}\text { Crating finding - } \\
\text { researcher is a } \\
\text { "passionate } \\
\text { participant" within } \\
\text { the world being } \\
\text { investigated }\end{array}$ & $\begin{array}{l}\text { Value mediated } \\
\text { findings - researcher } \\
\text { is a "transformative } \\
\text { intellectual” who } \\
\text { changes the social } \\
\text { world within which } \\
\text { participants live }\end{array}$ & $\begin{array}{l}\text { Findings probably } \\
\text { true - researcher is } \\
\text { value-aware and } \\
\text { needs to triangulate } \\
\text { any perceptions he or } \\
\text { she is collecting }\end{array}$ \\
\hline $\begin{array}{l}\text { Common } \\
\text { methodologies }\end{array}$ & $\begin{array}{l}\text { Mostly concerns with } \\
\text { a testing of theory. } \\
\text { Thus mainly } \\
\text { quantitative, methods } \\
\text { such as: survey, } \\
\text { experiments, and } \\
\text { verification of } \\
\text { hypotheses }\end{array}$ & $\begin{array}{l}\text { In-depth unstructured } \\
\text { interviews, } \\
\text { participant } \\
\text { observation, action } \\
\text { research, and } \\
\text { grounded theory } \\
\text { research }\end{array}$ & $\begin{array}{l}\text { Action research and } \\
\text { participant } \\
\text { observation }\end{array}$ & $\begin{array}{l}\text { Mainly qualitative } \\
\text { methods such as case } \\
\text { studies and } \\
\text { convergent } \\
\text { interviews }\end{array}$ \\
\hline
\end{tabular}

Then, students are introduced to the three dimensions of action research (Noffke, 2009): Personal, professional and political (Fig. 2)

Figure 2: Dimensions in action research

These conceptualizations of action research allow students to position themselves as researchers when tackling a sustainability challenge in terms of research paradigm that may guide their inquiry, action research methodology that best fits the purpose of their research and underlying assumptions on the dimensions of their research practice.

Finally, students are trained in qualitative, quantitative and mixed research tools and methods typically used in action research: Conceptual maps, questionnaires, interviews, backcasting, complexity and network analysis, etc. 
At this point students are ready to apply the action research methodology (Fig. 3), following the action research loop of analysing-planning-acting-evaluating-reflecting in three cycles in order to frame the problem, intervene and evaluate the intervention.

They apply all their learning on Action Research in real sustainability projects under two active learning paradigms: Campus lab (Evans et al., 2015) and Service Learning (Sipos et al., 2008). Next section describes the projects that have been carried out during the three years of life of the course.

\section{Transdisciplinary approach}

Some specific course characteristics are related to three main aspects of transdisciplinarity, namely (Lang et al., 2012; Scholz, 2011):

- Transition of relevant real-life societal problems, with society

- Crossing boundaries for mutual learning processes on equal footing

- Knowledge co-creation and integration to achieve robust knowledge (solution-oriented, socially robust, and transferable)

On the one hand, in performing teams and research with societal individuals or groups (municipality technicians, citizens, practitioners, elderly...), different disciplines were combined to build the best way to perform the action.

In these mutual learning processes, in which ways of advancing research were built collaboratively (methods, spaces, tempos, target groups), the cultivation of many cognitive skills such as differentiating, reconciling and synthesising is performed. The reflexive, collaborative, method driven framework implies the promotion of student's interpersonal and intrapersonal learning, in which the attempt to converge at every turn requires the development of communication, interaction and action skills.

Finally, the common generation and integration of experiential knowledge and awareness of the participants in the research teams, results in fostering a sense of self-authorship and a situated, partial and perspectival notion of knowledge that they can use to respond to complex questions, issues or problems. Truth is situated, perspectival, discursive and informs and is informed by the team own sense of self-authorship (Haynes, 2002)

\subsection{Three years of training}

The course was born from convergence of two former courses: Interdisciplinary workshop and Sustainable Technology Innovation (STI) seminar, which used constructive and community oriented learning. In the Interdisciplinary workshop as a very powerful aspect was identified, its relationship with "real-life projects", and yet was missing methodological basis. Moreover, STI clearly showed its enormous potential to bring social needs to the world of ideas, beyond a learning space. STI had also a strong methodology aspect, appreciated by students. In this sense, both needs were clustered to perform a course that deepen into research methodologies, with a strong Td approach, to work real-life projects, with a sustainability science perspective.

The first year students of the action research workshop also participated in the STI seminar (https://is.upc.edu/seminaris-i-jornades/seminaris/std-2014), so that both the subject and the real-life projects developed were shared.

Figure 3: Action research cycles (Adapted from Coghlan and Brannick, 2014) 
The course is organized around current sustainability relevant topics, broadly related to unsustainability aspects which are analysed in study real-life projects in local real situations, needs or challenges. Table 2 show the general topics for each course, organisations who lead their own real-life projects and the research question for each of them.

Organisations are called for collaboration and they bring their current demands to be developed jointly by teams of students, professionals, faculty and researchers. Participating organisations come from the UPC itself and from civil society and collaboration has been performed under Campus Lab and Service Learning respectively, both as exercises of Active learning. The Campus Lab methodology is used because university as living labs can provide a potential holistic and iterative framework for the co-production of knowledge (Evans et al., 2015). Service learning is use as it is considered a strategy for action to achieve social transformation through education (Aramburuzabala, 2013). Real-life projects are constructed with the aim to both respond organisation requirements and enable students training and competence achievement.

Moreover, in order to deepen in transdisciplinary settings we include in the course senior citizens thorough "Aprendre amb la Gent Gran (Learning with elderly)": a social program for the elderly, of the Districte de Sarrià (Barcelona). The aim of the program is to bring together and to establish linkages between all the stakeholders and seniors. During 6 to 8 sessions, the elderly worked together with students in the co-elaboration of academic works (surveys, reports, videos, diffusion pamphlets...). Students have learnt about personal strategies to address issues of awareness, (i.e. how to relate to groups that do have experiential knowledge, which may be far from a scientific-technical one); to listen at the experience of people and to have strategies to frame problems for people to understand, feel affected and own those "global" problems. Table 2 shows a characterization and the main features of the real-life projects. All the real-life projects has been guided by a research question, posed to pull the thread of the investigation and agreed by all the participants, which has been one of the most challenging stages in the AR process, since it has meant identifying and characterizing the problem 
Table 2: Summary of the research projects process, research tools used and results

\begin{tabular}{|c|c|c|c|c|c|}
\hline Topic & Stakeholder & Real-life projects & Research question & Research tools & Results \\
\hline \multicolumn{6}{|l|}{2014} \\
\hline \multirow[t]{2}{*}{$\begin{array}{l}\text { Sustainable } \\
\text { clothing and } \\
\text { slow fashion }\end{array}$} & $\begin{array}{l}\text { Clean Clothes } \\
\text { Campaign (SL) }\end{array}$ & Spanish fashion in Morocco & $\begin{array}{l}\text { What a local clothing company can do to minimize } \\
\text { labour exploitation risk, when pushed to find } \\
\text { suppliers in Morocco? }\end{array}$ & $\begin{array}{l}\text { Literature } \\
\text { review, surveys }\end{array}$ & $\begin{array}{l}\text { Backasting } \\
\text { report }\end{array}$ \\
\hline & $\begin{array}{l}\text { Slow Fashion Spain } \\
\text { (SL) }\end{array}$ & $\begin{array}{l}\text { A local booming sustainable } \\
\text { clothing market }\end{array}$ & $\begin{array}{l}\text { What are barriers and challenges faced by } \\
\text { sustainable fashion initiatives in current market? }\end{array}$ & $\begin{array}{l}\text { Literature } \\
\text { review, surveys }\end{array}$ & $\begin{array}{l}\text { Backasting } \\
\text { report }\end{array}$ \\
\hline \multicolumn{6}{|l|}{2015} \\
\hline \multirow[t]{2}{*}{$\begin{array}{l}\text { Energy poverty } \\
\text { in Catalonia }\end{array}$} & \multirow{2}{*}{$\begin{array}{l}\text { Energy Bank } \\
\text { Association BE - } \\
\text { Municipalities } \\
\text { Premià/Sabadell (SL) } \\
\end{array}$} & $\begin{array}{l}\text { Detection of motivations to } \\
\text { participate in the BE in Premià }\end{array}$ & $\begin{array}{l}\text { What are the factors that influence the decision to } \\
\text { join or not of the driver group of BE? }\end{array}$ & $\begin{array}{l}\text { Surveys, } \\
\text { interview }\end{array}$ & $\begin{array}{l}\text { Clusters } \\
\text { analysis }\end{array}$ \\
\hline & & $\begin{array}{l}\text { Phase } 1 \text { of implementation of } \\
\text { the Energy Bank in Sabadell }\end{array}$ & $\begin{array}{l}\text { What key factors that encouraged real participation } \\
\text { in a local energy program can be used for BE? }\end{array}$ & Surveys, & $\begin{array}{l}\text { Report on } \\
\text { online poll }\end{array}$ \\
\hline \multirow{2}{*}{$\begin{array}{l}\text { Energy } \\
\text { inefficiency in } \\
\text { public } \\
\text { buildings-UPC }\end{array}$} & \multirow[t]{2}{*}{$\begin{array}{l}\text { Office of } \\
\text { Sustainability } \\
\text { OGSIO- UPC (CLab) }\end{array}$} & $\begin{array}{l}\text { Analysis of communication } \\
\text { networks in the performance } \\
\text { of POEs organization }\end{array}$ & $\begin{array}{l}\text { Does the current organizational structure of the } \\
\text { POEs, or does not, influence on the obtained } \\
\text { results? }\end{array}$ & $\begin{array}{l}\text { Surveys, } \\
\text { interview }\end{array}$ & $\begin{array}{l}\text { Report on } \\
\text { Network } \\
\text { Analysis }\end{array}$ \\
\hline & & $\begin{array}{l}\text { Reporting server "orphan } \\
\text { building" }(*) \text { energy } \\
\text { consumption }\end{array}$ & $\begin{array}{l}\text { What part of servers consumption can be attributed } \\
\text { to information management and which to use? } \\
\text { How to reduce their energy consumption? }\end{array}$ & $\begin{array}{l}\text { Surveys, } \\
\text { interview }\end{array}$ & Report \\
\hline \multicolumn{6}{|l|}{2016} \\
\hline $\begin{array}{l}\text { Energy poverty } \\
\text { in Catalonia }\end{array}$ & $\begin{array}{l}\text { Energy BE - Premià } \\
\text { (SL) }\end{array}$ & $\begin{array}{l}\text { Phase } 2 \text { of BE implementation } \\
\text { in Premià: private sector }\end{array}$ & $\begin{array}{l}\text { What affordable and sustainable offer could } \\
\text { facilitate the organizations involvement to BE? }\end{array}$ & Focus groups & $\begin{array}{l}\text { Strategy } \\
\text { approach design }\end{array}$ \\
\hline \multirow[t]{2}{*}{ Gas Geopolitics } & \multirow[t]{2}{*}{$\begin{array}{l}\text { OdG- Debt } \\
\text { Observatory in } \\
\text { Globalization (SL) }\end{array}$} & $\begin{array}{l}\text { MIDCAT, huge construction } \\
\text { of a mega- pipeline for gas } \\
\text { interconnection France-Spain }\end{array}$ & $\begin{array}{l}\text { What is the capacity of this civil organized } \\
\text { campaign facing to maximize transparency and } \\
\text { public accountability? }\end{array}$ & $\begin{array}{l}\text { Data analysis, } \\
\text { surveys }\end{array}$ & Policy paper \\
\hline & & $\begin{array}{l}\text { Gas imports of the Port of } \\
\text { Barcelona }\end{array}$ & $\begin{array}{l}\text { What is the city responsibility on the perpetuation } \\
\text { of fuel energy model based on natural gas? }\end{array}$ & $\begin{array}{l}\text { Data analysis, } \\
\text { surveys }\end{array}$ & Policy paper \\
\hline $\begin{array}{l}\text { Communities } \\
\text { for energy } \\
\text { performance }\end{array}$ & $\begin{array}{l}\text { UPC Energia } 2020 \\
\text { (CLab) }\end{array}$ & $\begin{array}{l}\text { Energy Hackathon design for } \\
\text { developing sustainable energy } \\
\text { projects at UPC }\end{array}$ & $\begin{array}{l}\text { What kind of activity could be proposed to practice } \\
\text { sustainable energy at campus? }\end{array}$ & $\begin{array}{l}\text { Focus groups, } \\
\text { interviews, pilot }\end{array}$ & $\begin{array}{l}\text { Guide: } 1^{\text {st }} \text { UPC } \\
\text { Energy } \\
\text { Hackaton }\end{array}$ \\
\hline $\begin{array}{l}\text { UPC's water } \\
\text { management } \\
\text { teaching }\end{array}$ & $\begin{array}{l}\text { EWB- Engineers } \\
\text { Without Borders (SL) }\end{array}$ & $\begin{array}{l}\text { What kind of water } \\
\text { management is promoted at } \\
\text { UPC? }\end{array}$ & $\begin{array}{l}\text { Responds curriculum and UPC research at ensuring } \\
\text { the human right to water? }\end{array}$ & $\begin{array}{l}\text { Surveys, } \\
\text { interview, } \\
\text { network analiss }\end{array}$ & $\begin{array}{l}\text { Mapping of } \\
\text { relationships }\end{array}$ \\
\hline
\end{tabular}




\subsection{Course Assessment}

The assessment in the course is design to evaluate, the learning of the students and the course itself.

At the end of the course, students have to deliver two reports. A first report where they analyse all the AR process that they have applied reflecting on: the research paradigms, AR types and its dimensions, research tools used, AR cycles applied and the results obtained. A second report is the result of their research to be delivered to the "client" (guide, policy paper, communication strategy, etc.). Those reports are shown in an oral defence to all the stakeholders and clients, student mates and faculty.

Faculty assesses the AR report using a rubric (Craig, 2009), the rubric is also used by the students in the peer-assessment (Topping, 1998). Moreover stakeholders/clients evaluate the results provided by the students.

In order to evaluate the course, two explicit reflexive questions are asked to the students: What have I learned in this course? And, What do I thing about the course (structure, organization, timing, projects, etc.)? The results of the students' reflexions have been clustered in table 3 .

Table 3: Reflections of students about their learning and the course

Topic

Research methodologies

Relevant comments from students

Qualitative and Quantitative approaches are needed to see beyond the numbers.

I learned the relevance of qualitative aspects as we learned more from direct interaction with people than with quantitative data obtained by " $R$ software".

The management of relations with qualitative research, which is not usually taught in tech universities, have been very stimulating Qualitative data from interviews is a very inspiring process

Transdisciplinarity I have learned the relevance of stakeholders and the role they play.

茵 Real-life projects

Mutual learning

To participate in a real project and in touch with real stakeholders have been very interesting I liked to work in real projects We learn to work with people from different disciplines and to improve our communication skills when working with professionals with different project management schemes

We learn to be more tolerant with our group mates that have different background and ways of working.

The most valuable point was the interaction with stakeholders from other disciplines, listening their points of view and experiences in the topic.

Robust knowledge $\quad$ To realise that the different needs and concerns of stakeholders may shake the project process.

\begin{tabular}{ll} 
Discussions in class & $\begin{array}{l}\text { Which I liked the most was the organization and group work in class, } \\
\text { allowing to listening and learning from each other }\end{array}$ \\
\hline Low directedness & $\begin{array}{l}\text { There were many expectations at the beginning from all stakeholders and } \\
\text { we feel a bit lost } \\
\text { The goal of the research had to be defined between the stakeholders which } \\
\text { delayed the project, and was time consuming } \\
\text { The planning was confused and it took time to our self-organization with } \\
\text { the stakeholders } \\
\text { I think that this course give us too much freedom to make our choices, } \\
\text { depending on the stakeholders we were discussing the goal were } \\
\text { changing... }\end{array}$
\end{tabular}



Comprehensive
The course should be run at the first semester as a course that uses the
project
knowledge of the other courses that we take simultaneously in a
comprehensive real-live project.
It will be interesting to integrate more than one course in a project like
this, so we will have more time to perform a better project.

In relation to the learning process, most students appreciate: i. learning with mixed research methodologies and tools; ii. dealing with stakeholders' interest and their relevant role in sustainability challenges; iii. the need of Td approaches; and iv. teambuilding. In relation to the course, they appreciate: i. the real-life projects both Service learning and Campus Lab with real stakeholders/clients; ii. the group work sessions in the classroom with interesting discussions and reflexions on the project process. The main criticisms were related to the low degree of directedness at the beginning that for some was very frustrating, (the low directedness was deliberate in order to train students in dealing with stakeholders' different interests in real settings). In order to decrease the frustration among students, the course coordinators introduced an emotional intelligence workshop in the course (see next section). Another issue for improvement is that students feel overwhelmed with project work as this course is run simultaneously with other 6 courses and most of them have project work. Students suggested that there should be a comprehensive project for the whole semester where each course can contribute from its theme. This suggestion is taking seriously by the master coordination unit and we are now redefining the master structure.

\subsection{Emotional Intelligence module}

As commented before students longed for some capacity to bring back the "energy of frustration" related to the project uncertainty and to be able to give a positive approach to obtain a final result, "having patience" to develop and obtain results. At the same time they claimed for strengthening the group's relationship as necessary to feel comfortable in a work dynamics which demands more participation, better communication and somehow to get out of the self comfort zone.

Students realized that as professionals they should face situations in which have to: manage emotions; solve unexpected situations; solve frustrating situations in the workplace; and of course, manage teams. We decided to offer a different approach to their understanding, posing that many times this kind of situations may be approached by means of generating situations of empathy to ensure that participants can relax and create new common codes.

The module aims to allow students obtaining some experiential knowledge related to emotional intelligence and what are the related competences. These interpersonal competences, related to emotional intelligence are rarely included in curricula, although they have been widely studied and claimed (previuos works: Kunnanatt, 2004; Barth et al., 2014; Dlouha and Burandt, 2015).

Regarding the structure of the module (session of 2,5h), it starts with a framing theoretical introduction about emotional intelligence (see Gardner, 2001; Bisquerra, 2007), multiple intelligences theory (Mayer \& Salovey, 1997; Goleman, 1996) and related competences, always in the framework of sustainability (Lambrechts et al., 2013; Wiek, 2011).

After they experience some exercises or dynamics proper to therapeutic theatre. The module follows the thread of the 5 domains of emotional competence: emotional awareness, emotional regulation, 
emotional autonomy, social competence, skills for life and well-being, proposed by GROP ${ }^{1}$. After an initial group distension dynamic, the module is conducted, through dramatized exercises.

Participants recognize in an experiential way what are the emotions involved in each of these domains of EI, self-competence in all of them and how emotions can be perceived and expressed, understand, regulated and facilitated. Furthermore, one of the students contributed as reflection that "I considered as an great enjoyment not only to find out how a group dynamic is working, also to see himself acting as an individual integrated in a wider sense, but also to learn about its own consciousness and capacity of nonverbal communication and awareness".

\section{Conclusions}

After the three years of the programme, we have observed that students set out the importance of some topics and the difficulty to hold them. On the one hand, they realized the significance of framing an investigation under a research methodology that allows bringing research to the community, enhancing transdisciplinarity in any initiative or action. Difficulties appeared at different points in the process, starting from the very beginning, when the problem formulation proved to be one of the most arduous task in the process. Students apprehend how the perception of an issue from distinct perspectives and motivations directly influences the approach to the problem. The achievement of a joint formulation of the problem has boosted the knowledge creation process Another challenge arise with the accompaniment of stakeholders and the recognition of their role, during the whole process, due to that engineering students are not usually trained to work in wicked problems and moreover to work together with stakeholders. In this sense collaboration and communication with stakeholders was also challenging, being the most successful those capable of to incorporate and complement the experiences and expertise of others when working in their teams (Wiek et al., 2015). Interpersonal skills have also been enhanced with the participation of the senior learning program Aprendre amb la Gent Gran that deepened in an intergenerational and interpersonal perspective; moreover the relationship with the elderly has provided values and communication skills to students.

Finally, it is relevant to highlight that during the process students faced conflict and frustration situations, within their team and with stakeholders. To face that, an Emotional Intelligence module was introduced in the workshop and helped students to solve some paralyzing situations, which could have stopped the progress of the project. Therefore we suggest that engineering students need specific training in transdisciplinary research and conflict resolution, otherwise they could collapse in frustration when dealing with real transdisciplinary sustainability transitions.

\section{References}

Aramburuzabala P (2013) Aprendizaje-Servicio: Una herramienta para educar desde y para la justicia social. Revista Internacional de Educación para la Justicia Social 2(2):5-11.

Barcelona Declaration (2004) Engineering education in Sustainable Development Conference Barcelona.

Barth M, Adomßent M, Fischer D, Richter S, Rieckmann M (2014) Learning to change universities from within: A service-learning perspective on promoting sustainable consumption in higher education. Journal of Cleaner Production 62:72-81.

\footnotetext{
${ }^{1}$ GROP: Psychopedagogical Counseling Research Group. MIDE, Faculty of Education. University of Barcelona. http://www.ub.edu/grop/
} 
Baum F, MacDougall C, Smith D (2006) Participatory action research. Journal of epidemiology and community health 60(10):854-857.

Bisquerra R, Pérez N (2007) Las competencias emocionales. Educación XXI 10:61-82

Carr W, Kemmis S (2009) Educational action research: A critical approach. The Sage handbook of educational action research 74-84.

Coghlan D, Brannick T (2014) Doing action research in your own organization. Sage.

Coughlan P, Coghlan D (2011) Collaborative strategic improvement through network action learning: The path to sustainability. Edward Elgar Publishing.

Craig DV (2009) Action research essentials (Vol. 11). John Wiley \& Sons

Dlouhá J, Burandt S (2014) Design and evaluation of learning processes in an international sustainability oriented study programme. In search of a new educational quality and assessment method. Journal of Cleaner Production 106:247-258

Edwards A, Talbot R (2014) The hard-pressed researcher: a research handbook for the caring professions. Routledge.

Evans J, Jones R, Karvonen A, Millard L, Wendler J (2015) Living labs and co-production: university campuses as platforms for sustainability science. Current Opinion in Environmental Sustainability, 16:1-6.

Gardner H (2001) La inteligencia reformulada. Barcelona, Paidós.

Goleman D (1996) Inteligencia emocional. Barcelona, Kairós.

Haynes C (2002) Introduction: Laying a Foundation for Interdisciplinary Teaching. In Haynes, C. (ed.) Innovations in Interdisciplinary Teaching. Washington: American Council on Education / Oryx Press,11-22.

Kember D (2000) Action learning and action research: Improving the quality of teaching and learning. Psychology Press.

Kemmis S. (1985) Action Research and the politics of reflection. Reflection: Turning experience into lerarning 139-163.

Kunnanatt JT (2004) Emotional intelligence: The new science of interpersonal effectiveness. human resource development quarterly, 15(4):489-495.

Lambrechts W, Mulà I, Ceulemans K, Molderez I, Gaeremynck V (2012) The integration of competences for sustainable development in higher education: an analysis of bachelor programs in management. Journal of Cleaner Production 48(6):65-73.

Lang D J, Wiek A, Bergmann M, Stauffacher M, Martens P, Moll P, Swilling M (2012)

Transdisciplinary research in sustainability science: practice, principles, and challenges. Sustainability Science 7(S1):25-43.

Martens P (2006) Sustainability: science or fiction? Science, Practice, \& Policy 2(1):36-41. 
Mayer JD, Salovey P (1997) What is emotional intelligence? In P. Salovey \& D. Sluyter (Eds). Emotional development and emotional intelligence: Implications for educators (3-31). New York: Basic Books.

Noffke SE, Somekh B (Eds.) (2009) The Sage handbook of educational action research. Sage.

Noffke SE (2009) Revisiting the Professional, Personal, and Political Dimensions of Action Research. In Noffke, S. E., \& Somekh, B. (Eds.). The Sage handbook of educational action research. Sage: 6-30.

Revans RW (2011) ABC of action learning. Gower Publishing, Ltd.

Scholz RW (2011) Environmental literacy in science and society. From knowledge to decisions. Cambridge University Press, Cambridge, UK.

Seager T, Selinger E, Wiek A (2012) Sustainable engineering science for resolving wicked problems. Journal of Agricultural and Environmental Ethics, 1-18. doi: 10.1007/s10806-011-9342-2 123

Segalas J, Mulder KF, Ferrer-Balas D (2006) Embedding sustainability in engineering education. Experiences from Dutch and Spanish Technological universities. Conference: Higher Education for Sustainable Development: New Challenges from a Global Perspective. Luneburg.

Segalas J, Mulder KF, Ferrer-Balas D (2010) What do engineering students learn in sustainability courses? The effect of the pedagogical approach. Journal of Cleaner Production 18(3):275-284

Sipos Y, Battisti B, Grimm K (2008) Achieving transformative sustainability learning: engaging head, hands and heart. International Journal of Sustainability in Higher Education 9(1):68-86.

Sobh R, Perry C (2005) Research Design and data analysis in realism research. European Journal of Marketing 40(11/12):1194-1209.

Sterling S (2005) "Higher education, sustainability, and the role of systemic learning", in Corcoran, P.B., Wals, A.E.J. (Eds),Higher Education and the Challenge of Sustainability: Problematics, Promise and Practice, Kluwer, Boston, MA:49-70.

The WorldWatch Institute (2012) State of the world 2012. Moving Toward Sustainable Prosperity.

Topping K (1998) Peer assessment between students in colleges and universities. Review of educational Research 68(3):249-276

Tripp DH (1990) Socially critical action research. Theory into practice 29(3):158-166.

Wallace M (1987) A historical review of action research: some implications for the education of teachers in their managerial role. Journal of Education for Teaching 13(2):97-115.

Wiek A, Withycombe L, Redman CL (2011) Key competencies in sustainability: a reference framework for academic program development. Sustainability Science 6(2):203-218.

Whitehead J, McNiff J (2002) Action research. Principles and Practice. London: Routledge Falmer. McNiff, Jean.

Yearworth M (2016) Sustainability as a 'super-wicked' problem; opportunities and limits for engineering methodology. Intelligent Buildings International 8(1):37-47. 